\title{
Heritability Analysis of Local Corn Cultivars from Kisar Island Southwest Maluku After Induced with Colchicine
}

\author{
Hermalina Sinay*, Jonetha Tanrobak \\ Biology Education Program, Faculty of Teaching and Education, Universitas Pattimura, Indonesia \\ *Email: herlinbio@yahoo.co.id
}

Submitted: 21 January 2020. Revised: 11 February 2020. Accepted: 20 March 2020

\begin{abstract}
In the plant breeding program, selection is one process which aimed to obtain some varieties with superior traits. Within this process, one of criteria that must be consider is the wide genetic diversity of the plant which was selected, and how these traits are inherited. The purpose of this research was to determine (1) the influence of cultivar differences and the colchicine concentration towards the growth and production of local corn cultivar from Kisar Island Maluku, (2) to determine the heritability of growth and production variables after induced with colchicine. Completely randomized block design was used in this research with factorial design that consist of two factors i.e corn cultivar and colchicine concentration. The research procedure starts from field and seed preparation, immersion of seed into the colchicine solution, transplantation of seed into the field, plant maintenance, and harvesting. The variable measured including growth and production variables of corn. The analysis of variance showed a significant effect of cultivar differences on all growth and production variables ( $\mathrm{p}$ value $>0.05$ ), while colchicine concentration only showed a significant effect toward the plant height and number of seed per ear. The heritability analysis result showed that all variables observed were in high category. The different corn cultivars have a significant effect on all the growth and production, while the colchicine concentration only affect the plant height and number of seed per ear, and the heritability were in high category. This research provides useful information to farmers how to use colchicine to trigger plant growth and production. It can be used as an information in selecting corn cultivars with high yield potential.
\end{abstract}

Key words: Local Corn; Colchicine; Heritability

How to Cite: Sinay, H., \& Tanrobak, J. (2020). Heritability Analysis of Local Corn Cultivars from Kisar Island Southwest Maluku After Induced With Colchicine. Biosaintifika: Journal of Biology \& Biology Education, 12 (1), 119-124

DOI: http://dx.doi.org/10.15294/biosaintifika.v12i1.19847

\section{INTRODUCTION}

Corn (Zea mays L.) is one of the main food source that is very important in Indonesia, because corn is the second source of carbohydrate after rice. In Indonesia, corn demand increase along with the improvement of living standarts and quality. As same as a socio-economic of people and also in industries since it was used as a main source in manufacturing of corn cereals, corn oil, corn sugar, woof, or other based corn food, as well as in medicine (Kumar \& Jariyah, 2013).

According to Swastika et al. (2011) and Kariyasa et al. (2012), since 20 `s, on developing country such as in Indonesia, the increasing in corn demand for consumption and woof is around $10-15 \%$. By the increasing of corn demand, the increase of corn production is also being pursued. However there has not been a significant increase of corn production in Indonesia, in fact, there has been a decline mainly in Java Island, Nusa Tenggara and Maluku.

Facing this kind of problem, we need an effort to increase the corn production that should be done by utilizing fields located outside of Java Island. This is because basically areas outside of Java Island has potential to be developed and enlarged as corn field.
The other thing is that other areas in Indonesia also have local corn cultivars that have an ability to adapt to the environment such as specific agro-climate, which is compatible to be cultivated in local areas.

Maluku, mainly on Southwest Maluku, is one area which has potential for corn development. In this area, corn is the main staple food (Susanto \& Sirappa, 2005), and already been cultivated in every single planting seasons (Sinay \& Karuwal, 2017). According to Badan Pusat statistik Provinsi Maluku (2015), corn production in 2015 was estimated about 14.108 tons of dried corn, increased around 3.540 tons (33.50\%) compared to 2014 (around 10.568 tons of dried corn), where the highest increase occurred in Southwest Maluku.

The production improvement of corn could be done with lots of way, either by cultivation technique revitalization, technology application, cultivation area enlargement or by the genetic emendation. Genetic emendation could be done conventionally or by the modification. However, the modification technique or manipulation by using genetic engineering for emendation of genetic characters especially in corn could produce corn that contain gene from other organisms. That is why until now, the emendation still done conventionally. 
The use of colchicine to emend the plant genetic could be possible because of colchicine is an antimitotic substance that could change the micro-tubule orientation along the cell division in mitosis, and could also cause the changes in chromosome set from the very first characters, from diploid to triploid, tetraploid, or even polyploid. The polyploid character on plant could cause the plant to produce flower, fruit, and or bulb that majorly bigger.

Studies about colchicine effect in mutation induction and ploidization on plants especially in corn has already been reported by lots of researcher. Aili et al. (2016) reported that the treatment using colchicine give a significant influence on number of plants grow, plant height, stem diameter, number of leaf, number of stomata, stomata length, stomata width, male and female flowering time, and the leaf color on hybrid strain of corn in vegetative phase.

Winaryo et al. (2016) also reported that the treatment using colchicine on corn giving an influence on plant appearance of some characters such as height, diameter, and flowering time. Manzoor et al. (2019) stated that colchicine could induce polyploidy in plants because it was acted as an mitotic inhibitor during plant cell division by inhibiting the chromosome segregation.

With the using of colchicine, it is expected that higher result would be obtain for all variables that observed, and those variable could become an indicator in high class cultivar selection. The selection is one of program process in plant breeding and the benefit is to obtain the cultivar with a superior characters. In selection program, one of the condition that should be fulfilled is the genetic diversity on many characters and the heritability value of those characters. If one of character is heritable enough, the use of that character as an indicator of selection will be effective. The heritability of a character could be known by the heritability value $\left(h^{2}\right)$. Heritability is the ratio between the genetic diversity toward the phenotypic diversity (Ogunbayo et al., 2014).

The purpose of this research was to analize the influence of different corn cultivar and colchicine concentration towards the growth and production variables of local corn cultivar from Kisar Island Maluku. This study was also conducted to analize the heritability of growth and production variable from those local cultivars that induced with colchicine.

The advantage of this research was to reveal the effect of colchicine as an inhibitor of mitosis which could trigger polyploidization in plants. This can also give a scientific contributions to enrich the treasury of knowledge such as in Biological sciences and agriculture. On the other hand, it can contribute to the utilization of local corn cultivars that can be developed as superior corn cultivars with high growth and production traits.

\section{METHODS}

This research was a field experimental research and held on Biology Botanical Garden The Biology Program Pattimura University since January to June 2019. Randomized Complete Block Design with two factors was used. The first factor was corn cultivar consisted of seven local cultivars and the second factor was colchicine concentration which consisted of four levels $\left(\mathrm{K}_{1}: 0.01 \mathrm{ppm}, \mathrm{K}_{2}: 0.02 \mathrm{ppm}, \mathrm{K}_{3} 0.03\right.$ $\mathrm{ppm}$, and $\left.\mathrm{K}_{4}: 0.04 \mathrm{ppm}\right)$. The research procedure starts from field and seed preparation, immersion of seed into the colchicine solution, transplantation of seed into the field, plant maintenance, and harvesting.

Variables observed in this research was growth variable consisted of plant height, number of leaf, leaf length, and leaf width measured on 60 days after cultivation (before anthesis and silking), and the production variables consisted of ear weight, ear length, number of rows per ear, and number of seed per ear. The growth and production measurement results was analyzed using two ways Analysis of Variance (ANOVA) followed by Duncan Multiple Range Test (DMRT) at the significance level of $\alpha 0.05$. The ANOVA and DMRT was conducted with computer Program SPSS version 20.0 for Windows, while the heritability index was measured using a formula as proposed by Stansfield (2007), and clasified into three categories: low heritability $\left(\mathrm{h}^{2}<0.2\right)$, medium $\left(0.2<\mathrm{h}^{2}<0.5\right)$ and high $\left(\mathrm{h}^{2}>0.5\right)$ as proposed by Guo et al. (2015).

\section{RESULT AND DISCUSSION}

The growth variables data obtained from this study are plant height, leaf number (Table 1), leaf length, and leaf width (Table 2).

Based on the Table 1 and Table 2, when comparing all growth variables in the control and colchicine treatment, all local cultivars show that the value in control group is lower than the group induced with colchicine (treatment group). For the plant treated with colchicine, the highest value of plant height $(241.67 \mathrm{~cm})$, and leaf length $(93.05 \mathrm{~cm})$ were obtained by $\mathrm{J}_{6}$ cultivar (Kuning Dalam) and the highest value of leaf number (12.67 sheet) was obtained by $\mathrm{J}_{1}$ (Merah Delima Tongkol Cokelat), treated with colchicine concentration of $0.03 \mathrm{ppm}\left(\mathrm{K}_{3}\right)$. While the highest value of leaf width $(9.45 \mathrm{~cm})$ was obtained by $\mathrm{J}_{2}$ (Merah Delima Tongkol Putih) treated with 0.01 ppm colchicine $\left(\mathrm{K}_{1}\right)$. 
Table 1. Plant height and leaf number of local corn cultivars after induced with colchicine

\begin{tabular}{|c|c|c|c|c|c|c|c|c|c|c|}
\hline \multirow{2}{*}{ Corn Cultivar } & \multicolumn{5}{|c|}{ Plant height $(\mathrm{cm})$} & \multicolumn{5}{|c|}{ Leaf number (sheet) } \\
\hline & $\mathrm{K}_{0}$ & $\mathrm{~K}_{1}$ & $\mathrm{~K}_{2}$ & $\mathrm{~K}_{3}$ & $\mathrm{~K}_{4}$ & $\mathrm{~K}_{0}$ & $\mathrm{~K}_{1}$ & $\mathrm{~K}_{2}$ & $\mathrm{~K}_{3}$ & $\mathrm{~K}_{4}$ \\
\hline $\mathrm{J}_{1}$ (Merah Delima Tongkol Cokelat) & 136.00 & 180.33 & 200.00 & 190.67 & 185.67 & 8.33 & 11.33 & 11.67 & 12.67 & 10.67 \\
\hline $\mathrm{J}_{2}($ Merah Delima Tongkol Putih) & 137.33 & 187.67 & 174.67 & 178 & 184 & 7 & 11.33 & 12.33 & 11.33 & 11.33 \\
\hline $\mathrm{J}_{3}($ Merah Darah $)$ & 156.33 & 182 & 176.33 & 177 & 168.33 & 8.33 & 10.67 & 10.33 & 10.67 & 10.33 \\
\hline $\mathrm{J}_{4}($ Pulut $)$ & 131 & 168.67 & 179.67 & 180 & 174.67 & 6.33 & 10.33 & 10.33 & 10.67 & 10.33 \\
\hline $\mathrm{J}_{5}$ (Kuning Genjah) & 125.33 & 192 & 211.33 & 200.33 & 193 & 6.67 & 11 & 12 & 12 & 11.67 \\
\hline $\mathrm{J}_{6}($ Kuning Dalam $)$ & 146.67 & 219.33 & 213.33 & 241.67 & 212.33 & 8.33 & 11.67 & 11.67 & 12.33 & 11.67 \\
\hline $\mathrm{J}_{7}($ Putih $)$ & 158.67 & 179 & 171 & 216 & 159.67 & 7.67 & 9.33 & 10 & 11.33 & 9.33 \\
\hline
\end{tabular}

Table 2. Leaf lenght and leaf width of local corn cultivars after induced with colchicine

\begin{tabular}{|c|c|c|c|c|c|c|c|c|c|c|}
\hline \multirow{2}{*}{ Corn Cultivar } & \multicolumn{5}{|c|}{ Leaf Length $(\mathrm{cm})$} & \multicolumn{5}{|c|}{ Leaf width $(\mathrm{cm})$} \\
\hline & $\mathrm{K}_{0}$ & $\mathrm{~K}_{1}$ & $\mathrm{~K}_{2}$ & $\mathrm{~K}_{3}$ & $\mathrm{~K}_{4}$ & $\mathrm{~K}_{0}$ & $\mathrm{~K}_{1}$ & $\mathrm{~K}_{2}$ & $\mathrm{~K}_{3}$ & $\mathrm{~K}_{4}$ \\
\hline $\mathrm{J}_{1}$ (Merah Delima Tongkol Cokelat) & 58.71 & 81.14 & 77.29 & 72.34 & 70.82 & 6.45 & 8.87 & 8.39 & 8.75 & 8.24 \\
\hline $\mathrm{J}_{2}($ Merah Delima Tongkol Putih $)$ & 65.57 & 68.69 & 65.25 & 63.32 & 73.44 & 6.18 & 9.45 & 6.59 & 7.26 & 8.4 \\
\hline $\mathrm{J}_{3}($ Merah Darah $)$ & 60.75 & 77.21 & 75.57 & 72.78 & 70.41 & 6.67 & 8.4 & 7.94 & 7.69 & 7.41 \\
\hline $\mathrm{J}_{4}($ Pulut $)$ & 60.2 & 74.29 & 78.28 & 75.38 & 75.78 & 6.68 & 7.5 & 8.16 & 8.23 & 8.5 \\
\hline $\mathrm{J}_{5}($ Kuning Genjah $)$ & 50.15 & 82.17 & 89.37 & 81.58 & 79.73 & 5.64 & 8.48 & 8.8 & 8.76 & 8.76 \\
\hline $\mathrm{J}_{6}($ Kuning Dalam $)$ & 64.78 & 85.55 & 89.59 & 93.05 & 83.1 & 5.64 & 8.49 & 8.6 & 9.2 & 8.74 \\
\hline $\mathrm{J}_{7}($ Putih $)$ & 62.84 & 72.13 & 76.85 & 83.82 & 77.49 & 7.25 & 7.17 & 7.52 & 8.4 & 7.52 \\
\hline
\end{tabular}

Table 3. Ear weight and ear lenght of local corn cultivars after induced with colchicine

\begin{tabular}{lcccccccccc}
\hline \multirow{2}{*}{ Corn Cultivar } & \multicolumn{4}{c}{ Ear weight $(\mathrm{g})$} & \multicolumn{5}{c}{ Ear lenght $(\mathrm{cm})$} \\
\cline { 2 - 10 } & $\mathrm{K}_{0}$ & $\mathrm{~K}_{1}$ & $\mathrm{~K}_{2}$ & $\mathrm{~K}_{3}$ & $\mathrm{~K}_{4}$ & $\mathrm{~K}_{0}$ & $\mathrm{~K}_{1}$ & $\mathrm{~K}_{2}$ & $\mathrm{~K}_{3}$ & $\mathrm{~K}_{4}$ \\
\hline $\mathrm{J}_{1}$ (Merah Delima Tongkol Cokelat) & 83.3 & 196.67 & 166.67 & 135.00 & 136.67 & 9.00 & 24.25 & 14.7 & 13.63 & 13 \\
$\mathrm{~J}_{2}$ (Merah Delima Tongkol Putih) $)$ & 61.66 & 125.00 & 140.00 & 142.50 & 148.33 & 9.06 & 12.43 & 13.27 & 13.8 & 13.47 \\
$\mathrm{~J}_{3}$ (Merah Darah) & 50.00 & 115.00 & 115.33 & 105.00 & 100.00 & 8.89 & 13.13 & 12.53 & 12.13 & 12.1 \\
$\mathrm{~J}_{4}$ (Pulut) & 70.00 & 165.00 & 157.00 & 144.67 & 161.33 & 9.07 & 13.57 & 11.77 & 12.43 & 12.33 \\
$\mathrm{~J}_{5}$ (Kuning Genjah) & 58.33 & 163.33 & 166.67 & 148.33 & 166.67 & 8.9 & 15.27 & 15.13 & 14.07 & 15.7 \\
$\mathrm{~J}_{6}$ (Kuning Dalam) & 63.33 & 141.67 & 158.33 & 130.00 & 170.00 & 9.33 & 12.87 & 13.1 & 13.23 & 14.93 \\
$\mathrm{~J}_{7}$ (Putih) & 56.66 & 105.00 & 111.67 & 95.00 & 88.33 & 9.86 & 12.8 & 13.3 & 13.07 & 11.63 \\
\hline
\end{tabular}

Table 4. Number of rows per ear and number of seed per ear of local corn cultivars after induced with colchicine

\begin{tabular}{lcccccccccc}
\hline \multirow{2}{*}{ Corn Cultivar } & \multicolumn{4}{c}{ Number of rows per ear (rows) } & \multicolumn{5}{c}{ Number of seed per ear (seed) } \\
\cline { 2 - 10 } & $\mathrm{K}_{0}$ & $\mathrm{~K}_{1}$ & $\mathrm{~K}_{2}$ & $\mathrm{~K}_{3}$ & $\mathrm{~K}_{4}$ & $\mathrm{~K}_{0}$ & $\mathrm{~K}_{1}$ & $\mathrm{~K}_{2}$ & $\mathrm{~K}_{3}$ & $\mathrm{~K}_{4}$ \\
\hline $\mathrm{J}_{1}$ (Merah Delima Tongkol & & & & & & & & & & \\
Cokelat) & 9.33 & 15.3 & 14 & 11.3 & 13 & 182.00 & 385.67 & 320.33 & 260.67 & 292.33 \\
$\mathrm{~J}_{2}$ (Merah Delima Tongkol Putih) $)$ & 9.33 & 14 & 13.67 & 12.33 & 13 & 133 & 266.3 & 303.3 & 258.3 & 318.3 \\
$\mathrm{~J}_{3}$ (Merah Darah) & 9.67 & 13.33 & 13 & 12.67 & 11.33 & 155 & 355 & 324.7 & 290 & 244.7 \\
$\mathrm{~J}_{4}$ (Pulut) & 9.33 & 12.67 & 13 & 13.33 & 14 & 167 & 266.5 & 190.5 & 264 & 204.25 \\
$\mathrm{~J}_{5}$ (Kuning Genjah) & 9.67 & 12.67 & 13.33 & 12 & 13.33 & 103.5 & 387 & 350.67 & 311.67 & 348 \\
$\mathrm{~J}_{6}$ (Kuning Dalam) & 9.00 & 13 & 13.33 & 11.33 & 12.67 & 125.5 & 324.33 & 348.33 & 259.67 & 340.67 \\
$\mathrm{~J}_{7}$ (Putih) & 9.33 & 10.67 & 10.67 & 10.67 & 10 & 184.33 & 294.67 & 278.67 & 242.33 & 226 \\
\hline
\end{tabular}

Highest value of ear length $(15.7 \mathrm{~cm})$ was obtained from $\mathrm{J}_{5}$ (Kuning Genjah) with colchicine concentration of $0.04 \mathrm{ppm}\left(\mathrm{K}_{4}\right)$. The highest value of number of rows per ear (15.3 seed rows) was obtained from $\mathrm{J}_{1}$ (Merah Delima Tongkol Cokelat) with colchicine concentration of $0.01 \mathrm{ppm}\left(\mathrm{K}_{1}\right)$, and the highest number of seed per ear (387 seeds) was obtained from $\mathrm{J}_{5}$ (Kuning Genjah) with 0.01 ppm colchicine concentration $\left(\mathrm{K}_{1}\right)$ (Table 3 and 4$)$.

Although the mean of measurement result on growth and production variables of control group is lower than the treatment group (induced with colchicine), but the value of treatment group is not specific to one of colchicine concentration. This can be seen in the growth variables (plant height, leaf number, and leaf lenght). For those variables, the highest value was obtained on $0.03 \mathrm{ppm}$ colchicine concenration $\left(\mathrm{K}_{3}\right)$, while for the leaf width, the highest value was obtained on the $0.01 \mathrm{ppm}$ colchicine concentration $\left(\mathrm{K}_{1}\right)$.

Similar to this result, for the production variables. The highest value of ear weight with no husk, and number of seed per ear was obtained from 0.01 of colchicine $\left(\mathrm{K}_{1}\right)$, while for ear length the highest 
value was obtained on 0.04 ppm colchicine concentration $\left(\mathrm{K}_{4}\right)$. This shows that the treatment using the same colchicine concentration is not constantly giving result to the highest, either growth or production of those cultivar.

As shown in the treatment using colchicine, corn cultivar give a different results on either the growth or the production variables. The highest result of plant height and leaf length was obtained from $\mathrm{J}_{6}$ cultivar (Kuning Dalam). While, for number of leaf and leaf width, the highest result was obtained from $\mathrm{J}_{1}$ (Merah Delima Tongkol Cokelat) and $\mathrm{J}_{2}$ cultivar (Merah Delima Tongkol Putih) respectively.

In the production variables, different result is shown by each kind of cultivar. The highest ear weight and seed rows per ear were obtained from $\mathrm{J}_{1}$ cultivar (Merah Delima Tongkol Cokelat). While, for the highest ear length and number of seed per ear were obtained from $\mathrm{J}_{5}$ cultivar (Kuning Genjah). This result shows that the same cultivar does not constantly have a high value on every single variable observed. Also, on cultivar with all high growth variables, it does not constantly have high value on all production variables.

The result of ANOVA showed that the different treatment gave a significant effect toward all growth and production variables that has been observed $(\mathrm{p}$ value $<0.05$ ), while the colchicine concentration has significant effect only in plant height and number of seed per ear (Table 5).

Although the highest mean result of growth and production variables was obtained on the treatment group (induced with colchicine) compare to the control group, but the results of ANOVA (Table 5) showed that there is no significant effect of treatment group (colchicine concentration) towards most of variables that have been analyzed, except for the plant height and number of seed per ear. Besides those two variables, all growth (number of leaf, leaf length andleaf width), and production variables (ear weight, ear length, and number of seed rows per ear) are not influenced by the differences in the colchisine concentration. This is probably caused by the concentration of colchisine was too low, or caused by the improper of immersion time. According to Aili et al. (2016) colchicine must be used with the right concentration, because if the concentration and time of immersion are not right, then the polyploidy cannot be achieved.

The result of two ways ANOVA showed that different corn cultivar had significant effect to all growth and production variables observed. This means that through this research, colchicine is unable to trigger growth and production of corn (except the height and number of seed), while overall result obtained shows that either the growth or production variables indeed depend on the difference in each cultivar itself.

This result was in line with the statement by Gnanamurthy et al. (2012) which stated that chemical mutagen can lead the decrease in morphological traits of corn such as plant height, leaf number, weight of 100 grains, cob lenght, and number of cob. This was caused by there was a maximum threshold of each plant in their ploidization. If the concentration or level of mutagen was exceeds the threshold, the plant will be abnormal or die (Kadi, 2007). Besides the mutation factor, a decrease of the post-harvest character can also be caused by a decrease in the vegetative character of the plant which can interfere the process of forming assimilates.

Based on this result of ANOVA, the heritability index then was analyzed to ensure whether the result obtained is caused by the differences in cultivar or by the interaction between cultivar and environmental factor. This is based on the reason that either growth or production variable of a plant depend on the genetic factor in the plant itself, the environmental factor, and or the interaction of both. The heritability test result is shown in Table 6.

Table 5. Result of two ways ANOVA of growth and production variables

\begin{tabular}{llcc}
\hline \multirow{2}{*}{ Variables } & Sub & \multicolumn{2}{c}{ Analysis of variance result (p value 0.05*) } \\
& variables & $.000^{*}$ & $.001^{*}$ \\
\hline \multirow{6}{*}{ Growth } & Plant Height & $.000^{*}$ & .467 \\
& Numbers of Leaf & $.000^{*}$ & .483 \\
& Leaf Length & $.000^{*}$ & .697 \\
& Leaf Width & $.000^{*}$ & .612 \\
Production & Ear Weight & $.000^{*}$ & .536 \\
& Ear Length & $.000^{*}$ & .150 \\
& Number of seed rows per ear & $.000^{*}$ & $.022^{*}$ \\
\hline
\end{tabular}

$*$ : significance effect on $\alpha 0.05$ 
Table 6. The result of heritability analysis on Growth and Production variables

\begin{tabular}{llcc}
\hline Variables & Sub variables & Heritability value $\left(\mathrm{h}^{2}\right)$ & Category \\
\hline Growth & Plant Height & 0.88 & High \\
& Number of leaf & 0.75 & High \\
& Leaf Length & 0.94 & High \\
& Leaf Width & 0.57 & High \\
Production & Ear Weight on harvesting & 0.78 & High \\
& Ear Length & 0.52 & High \\
& Number of seed rows per ear & 0.85 & High \\
& Number of seed per ear & 0.71 & High \\
\hline
\end{tabular}

As shown in Table 6, the heritability value of all variables was in high category. This means that those kind of variables depend on differences of corn cultivar. This result is in line with the result of ANOVA that shows that the first factor (difference of corn cultivar) has a significant effect towards all growth and production variables. This means that either growth or production variables of local corn cultivar from Kisar Island Southwest Maluku regency are indeed caused by the difference of those cultivar. This means that there is differences in genetic composition of each cultivar. So that, those cultivar giving different responses either in growth or production variables, while induced with colchicine with different concentration did not influence all observed variables. This is in line with the research result reported by Sinay et al. (2016) which stated that different kind of corn cultivar give a significant influence towards all phenotypic character that consist of growth traits (height, number of leaf, leaf length, and leaf width), physiological traits (prolin level, male flower ages, female flower ages, anthesis-silking interval), anatomical traits (number of stomata, density, and stomata index), also the production including number of ear, ear length, ear diameter,ear weight with no air dry mass, ear weight with no dry oven, ear water level with no husk in harvesting, ear weight water level on $12 \%$, number of seed rows, and number of seed per ear on local corn cultivar that cultivated in it`s natural habitat in Kisar Island Southwest Maluku regency.

The significance influence of corn cultivar toward the phenotypic traits diversity as reported by Sinay et al. (2016), and also found on this research, probably happen because of the differences in genetic composition among each local cultivar. This is also in line with $\mathrm{Li}$ et al. (2018) who stated that the phenotypic appearance of a plant depend on its genotype factor. Subekti and Jafri (2011) also stated that the character diversity of each cultivar or variety is caused by the difference on genotype of that plant. Otherwise, Gratani (2014) also stated that different kind of genotype could give a different responses on the same environment, while Ncube et al. (2012) stated that alt- hough those plant grow in the same environment, but if each individual has a differences in genotype composition, the response to their growth environment of each individual will be different.

Therefore, it could be say that local cultivar from Kisar Island that cultivated by the local farmer, and being observed in this research with using colchicine with various concentration indeed have a difference in genetic substances. The differences in genetic substances expressed in form of phenotype or the morphology, so when those corn was planted in the same environment, those cultivar constantly giving phenotypic appearance in form of height, leaf length, leaf width, ear weight, ear length, number of rows per ear, and number of seed per ear that quite various.

The novelty of this research is the using of colchicine as an antimitotic agents. This is due to the investigation about corn cultivars from Kisar Island still not well done expecially for the using of antimitotic agent to trigger plant growth and production. As mentioned by Anbarasan et al. (2013) that mutation techniques have been used to derive many varieties of food crops including corn. This type of genetic manipulation is frequently used in breeding plants to create genetic variability. According to Aliero (2006) and Bolbhat et al. (2012) that genetic variability is required for crop improvement including corn plants because with the genetic variability information, the new varieties can be generated. This research result is expected to be useful as an information to farmers about how to use colchicine to trigger plant growth and production. In addition, for instance, this can be used as information in selecting corn cultivars with high yield potential and in obtaining new traits, creating genetic variability and supplementing conventional breeding.

\section{CONCLUSION}

It can be conclude that the difference on cultivar giving a great significance toward the growth and production of local corn, while the colchicine concentration only influence the plant height and number of seed, but does not give any influence towards number 
of leaf, leaf length, leaf width, ear weight, ear length, and number of rows per ear. The heritability analysis shows that all variables observed categorized as high heritability.

\section{ACKNOWLEDGEMENT}

This research was funded by PT Indofood Sukses Makmur Tbk through the Program Indofood Riset Nugraha (IRN) 2019. Authors expres deepest gratitude for these funding.

\section{REFERENCES}

Aili, E.N., Respatijarti., \& Sugiharto, A.N. (2016). Pengaruh Pemberian Kolkisin Terhadap Penampilan Fenotip Galur Inbrida Jagung Pakan (Zea mays L.) Pada Fase Pertumbuhan Vegetatif. Jurnal Produksi Tanaman, 4(5), 370-377.

Aliero, A.A. (2006). Effect of Hydroxylamine on the Germination of and Growth of Sesame (Sesamum indicum). Journal of Plant Science, 1(4), 356-361.

Anbarasan, K., Sivalingam, D., Rajendran, R., Anbazhagan, M. \& Chidambaram, A.A. (2013). Studies on the Mutagenic Effect of EMS on Seed Germination and Seedling Characters of Sesame (Sesamum indicum L.) Var. TMV3. International Journal of Research in Biological Sciences, 3(1), 68-70.

Badan Pusat Statistik Provinsi Maluku. (2015). Maluku Dalam Angka. Ambon 2015

Bolbhat, S.N., Bhoge, V.D., \& Dhumal, K.N. (2012). Effect of Mutagens on Seed Germination, Plant Survival and Quantitative Characters of Horse Gram (Macrotyloma uniflorum (LAM.) VERDC). International Journal of Life Science and Pharma Research, 2(4), 130-136.

Gnanamurthy, S., Dhanavel, D., Girija, M. (2013). Effect of Gamma Radiation on the morphological characters of cowpea [Vigna unguiculata (L.) Walp.]. International Journal of Current Trends in Research, 2(1), 38-43.

Gratani, L. 2014. Plant Phenotypic Plasticity in Response to Environmental Factors. Advances in Botany. Volume 2014, Article ID 208747, 17 pages http://dx.doi.org/10.1155/2014/208747

Guo, Z., Chen, D., \& Schnurbusch, T. (2015). Variance Components, Heritability and Correlation Analysis of Anther and Ovary Size During the Floral Development of Bread Wheat. Journal of Experimental Botany, 66(11), 3099-3111.

Kadi, A. (2007). Manipulasi Poliploidi Untuk Memperoleh Jenis Baru Yang Unggul. Oseana, XXXII (4), 1-11.

Kariyasa, K,. Sinaga, B.M., \& Adyana, M.O. (2012). Proyeksi Produksi dan Permintaan Jagung, Pakan dan Daging Ayam Ras di Indonesia. Jurnal of Food Security and Agriculture, 1(1), 1-22.

Kumar, D., Jhariya, A.N. (2013). Nutritional, Medicinal and Economical Importance of Corn: A Mini Review. Research Journal of Pharmaceutical Sciences, 2(7), 7-8.

Li, X., Guo, T., Mu, Q., Li, X., \& Yu, J. (2018). Genomic and environmental determinants and their interplay underlying phenotypic plasticity. PNAS, 115(26), 6679-6684.

Manzoor, A., Ahmad, T., Bashir, M. A., Hafiz, I. A., \& Silvestri, C. (2019). Studies on Colchicine Induced Chromosome Doubling for Enhancement of Quality Traits in Ornamental Plants. Plants (Basel, Switzerland), 8(7), 194.

Ncube, B., Finnie, J.F., \& Van Staden, J. (2012). Quality from thefield: The impact of environmental factors as qualitydeterminants in medicinal plants. South $A f-$ rican Journal of Botany, 82(1),11-20.

Ogunbayo, A., Moussa, S., Ojo, D.K., Sanni, K., Akinwale, M.G., Toulou, B., Shittu, A., Emmanuel, I., Popoola, A., Daniel, I.O., \& Gregorio, G. (2014). Genetic Variation and Heritability of Yield and Related Traits in Promising Rice Genotypes (Oryza sativa L.). Journal of Plant Breeding and Crop Science, 6, 153-159.

Sinay, H., Aruningtyas, E.L., Harijati, N., \& Indriyani, S. (2016). Keragaman dan Kekerabatan Kultivar Jagung (Zea mays L.) Lokal Asal Pulau Kisar Kabupaten Maluku Berdasarkan Karakter Fenotip. Biopendix (Jurnal Biologi, Pendidikan, dan Terapan), 3 (1), 18-27.

Sinay, H., \& Karuwal, R.L. (2017). Genetic Variability of Local Corn Cultivars from Kisar Island Southwest Maluku Regency using Microsatellite Molecular Marker. Biosaintifika Journal of Biology \& Biology Education, 9 (3), 444-450.

Swastika, D.K.S., Agustian, A., \& Sudaryanto, T. (2011). Analisis Senjang Penawaran dan Permintaan Jagung Pakan Dengan Pendekatan Sinkronisasi Sentra Produksi, Pabrik Pakan, dan Populasi Ternak di Indonesia. Informasi Pertanian, 20(2), 65-75.

Stansfield, W.D. (2007). Genetika (edisi ke-4). Jakarta: Erlangga.

Subekti, A. \& Jafri. (2011). Penampilan Karakter Agronomis dan Hasil beberapa Varietas Jagung Pada Lahan Ultisol Singkawang Kalimantan Barat Paper presented at the Seminar Nasional Serealia.

Susanto, A.N. \& M.P. Sirappa. (2005). Prospek dan Strategi Pengembangan Jagung untuk Mendukung Ketahanan Pangan Di Maluku. Jurnal Litbang Pertanian 24(2): 70-79.

Winaryo, K.A.P., Sugiharto, A. N., \& Ainurrasjid. (2016). Penampilan Fenotipik 2 Galur Jagung (Zea mays L.) Akibat Pemberian Kolkhisin. Jurnal Produksi Tanaman, 4(2), 161-168. 